\title{
HISTÓRIA DO DESIGN GRÁFICO I NO CURSO DE DESIGN DIGITAL
}

Helena Rugai Bastos - helena@acordodesign.com.br - helenarugai@gmail.com

Unifieo

O Bacharelado em Design Digital do Centro Universitário Fieo - UNIFIEO - é oferecido desde 2001 em Osasco, cidade que faz parte da Região Metropolitana de São Paulo. 0 curso com 3180 horas tem duração de 4 anos e segue o regime seriado semestral. A Instituição oferece anualmente 120 vagas apenas no horário noturno.

A estrutura curricular do curso é organizada a partir de três eixos principais que se articulam, a saber, Fundamentação Cultural e de Pesquisa, Expressão e Criação, Sistemas de Produção em Mídia Digital e Interativa. Estes eixos são subdivididos em cinco grupos de disciplinas: fundamentação geral, humanista e da comunicação; fundamentação conceitual aplicada ao design visual e digital; fundamentação técnica; aplicação conceitual e técnica; aplicação prática. Os conteúdos abordados durante o curso não são estanques, assim algumas disciplinas enquadram-se em mais de uma área ou grupo.

A disciplina História do Design faz parte do grupo de componentes que propõem a formação no campo das humanidades, que discutem a cultura material e a produção de pesquisa científica, e que abordam os fundamentos e conceitos aplicados ao design. Este grupo é composto por disciplinas de fundamentação geral, humanista, que discutem os contextos sociológico, histórico, antropológico, artístico e cultural, métodos de pesquisa e de projeto, linguagem, comunicação e informação, além dos fundamentos do design, analisando técnicas e meios de representação. Fazem parte deste eixo Sociologia, Filosofia, Antropologia Visual, Psicologia, Metodologia do Estudo e da Pesquisa, Comunicação e Expressão, Ética e Legislação, História da Arte, História do Design Gráfico, Teoria da Criação, Metodologia Visual, Teoria da Comunicação, Planejamento da Comunicação, Direção de Arte, Ergonomia Visual- Interfaces.

Bastos, Helena Rugai. "História do Design Gráfico I no curso de Design Digital”, in Anais do 1o Seminário Paulista do ensino da história do design 2014 [= Blucher Design Proceedings, num.3, vol. 1]. São Paulo: 
Dividida em dois semestres sequenciais no primeiro ano do curso, a História do Design Gráficofornece subsídios para a constituição e ampliação da visão de mundo e do espírito crítico dos alunos, levando em conta o processo de criação do design, como produto e como forma de linguagem.

Ministrada no primeiro semestre do curso, a História do Design Gráfico I introduz os conceitos e fundamentos sobre design e propõem apresentar as principais questões históricas relacionadas à institucionalização da área e a constituição do campo de trabalho no exterior e no Brasil.Busca refletir sobre o processo de concepção e de produção de artefatos, de projetos gráficos, de informações visuais e imagens gráficas na história, levando em conta o desenvolvimento das técnicas de representação e de produção industrial, assim como da linguagem visual. Apesar do nome da disciplina propor o estudo apenas da história do design gráfico, são analisadas também as produções de artefatos, bem como a produção na área do design digital.

Levando em conta o perfil dos ingressantes da instituição e a formação de Ensino Fundamental e médio da região - Osasco, SP - é necessário, neste primeiro período, recuperar conteúdos sobre história geral, apresentando de maneira panorâmica as transformações econômicas, políticas e sociais dos séculos XVIII e XIX na Europa, Estados Unidos e Brasil. 0 estudo sobre a produção e a formação do campo de trabalho na área do design é iniciado a partir da Revolução Industrial. Esta opção se justifica na estrutura curricular do curso. No $1^{\circ}$ - semestre a disciplina Tipografia aborda contexto e a produção na história da escrita ocidental, o desenvolvimento do alfabeto, dos tipos e dos processos de impressão tipográfica. Desta maneira, é possível estudar a produção do design a partir da 2 ${ }^{\underline{a}}$ metade do século XIX até o fim da $2^{\underline{a}}$ Guerra Mundial.

A abordagem da disciplina busca a contextualização socioeconômica e de desenvolvimento de tecnologias aplicadas à produção do design em cada época. Desta maneira, são apresentadas vertentes e correntes do design nos vários períodos de maneira concomitante, privilegiando as produções nos Estados Unidos e na Europa, em especial Inglaterra, França, Alemanha, Rússia e Itália, além do Brasil. Durante o semestre são abordados os seguintes conteúdos:

- Conceito e fundamentos do design: terminologia, aplicações, atuação.

- Design e suas relações com a arte, as artes gráficas, as artes e ofícios.

- Definições e conceitos sobre design gráfico e digital.

- Transformações socioeconômicas, políticas e culturais nos séculos XVIII e XIX na Europa, EUA e Brasil.

- Formação do campo profissional no mundo.

- Cursos técnicos e superiores nos séculos XIX até os anos 1950. 
- Formação dos profissionais no Brasil, dos anos 1950 a 1980.

- Desenvolvimento do campo de1850 até anos 1950.

- A estrutura do curso contempla a realização de trabalhos práticos e projetos interdisciplinares organizados nos 8 semestres do curso. A disciplina História do Design Gráfico I, apoiada principalmente pela disciplina Tipografia, é responsável pela organização e coordenação dos projetos interdisciplinares, assim as temáticas abordadas têm relação à tipografia e à produção visual articuladas ao contexto histórico em diferentes momentos - do século XV à $1^{\underline{a}}$ metade do século XX no $1^{\circ}$ semestre do curso.

A avaliação é bimestral. No $1^{\circ}$ bimestre a nota é composta por exercício individual e em equipe. As temáticas variam de acordo com os textos selecionados no semestre. A atividade desenvolvida em equipe tem relação com o tema do projeto interdisciplinar. No $2^{\circ}$ bimestre os alunos são avaliados por meio de prova escrita individual sobre os conteúdos abordados na disciplina e pelo desenvolvimento do Projeto Interdisciplinar. Esta avaliação é realizada em orientações às equipes na apresentação do projeto. A nota final é resultante da média aritmética das duas avaliações.

Pelo fato da disciplina ser responsável pelo desenvolvimento do projeto Interdisciplinar, os alunos demonstram maior interesse e envolvimento. Esta condição contribui para que alguns percebam a articulação entre teoria e prática, bem como a importância da contextualização históricapara a fundamentação de projeto. Porém, nem todos admitem a importância da relação entre a prática de projetoe a pesquisa da produção do design na história.

\section{REFERÊNCIAS}

BRASIL. Ministério da Educação. Secretaria de Educação Superior. Referenciais Curriculares Nacionais dos Cursos de Bacharelado e Licenciatura. Brasília, DF, 2010. BRASIL. Conselho Nacional de Educação. Câmara de Educação Superior. Resolução no 5 , de 08 de março de 2004. Aprova as Diretrizes Curriculares Nacionais do Curso de Graduação em Design e dá outras providências. Diário Oficial da União, Brasília, DF, 15 de mar. 2004, Seção 1, p. 24. Republicada no Diário Oficial da União, Brasília, DF, $1^{\circ}$ abr. 2004, Seção 1, p. 19.

Centro UniVersitáRio FIEO. Projeto Pedagógico do Curso Superior de Design Digital. Osasco, SP, 2007. 